\title{
DNAzyme-mediated recovery of small recombinant RNAs from a 5 S rRNA-derived chimera expressed in Escherichia coli
}

\author{
Yamei Liu', Victor G Stepanov ${ }^{1}$, Ulrich Strych¹, Richard C Willson ${ }^{1,2}$, George W Jackson³ ${ }^{3}$ George E Fox ${ }^{1 *}$
}

\begin{abstract}
Background: Manufacturing large quantities of recombinant RNAs by overexpression in a bacterial host is hampered by their instability in intracellular environment. To overcome this problem, an RNA of interest can be fused into a stable bacterial RNA for the resulting chimeric construct to accumulate in the cytoplasm to a sufficiently high level. Being supplemented with cost-effective procedures for isolation of the chimera from cells and recovery of the recombinant RNA from stabilizing scaffold, this strategy might become a viable alternative to the existing methods of chemical or enzymatic RNA synthesis.

Results: Sequence encoding a 71-nucleotide recombinant RNA was inserted into a plasmid-borne deletion mutant of the Vibrio proteolyticus 5S rRNA gene in place of helix III - Ioop C segment of the original 5S rRNA. After transformation into Escherichia coli, the chimeric RNA (3xpen aRNA) was expressed constitutively from E. coli rrnB P1 and P2 promoters. The RNA chimera accumulated to levels that exceeded those of the host's 5 S rRNA. A novel method relying on liquid-solid partitioning of cellular constituents was developed for isolation of total RNA from bacterial cells. This protocol avoids toxic chemicals, and is therefore more suitable for large scale RNA purification than traditional methods. A pair of biotinylated 8-17 DNAzymes was used to bring about the quantitative excision of the 71-nt recombinant RNA from the chimera. The recombinant RNA was isolated by sequence-specific capture on beads with immobilized complementary deoxyoligonucleotide, while DNAzymes were recovered by biotin affinity chromatography for reuse.

Conclusions: The feasibility of a fermentation-based approach for manufacturing large quantities of small RNAs in vivo using a "5S rRNA scaffold" strategy is demonstrated. The approach provides a route towards an economical method for the large-scale production of small RNAs including shRNAs, siRNAs and aptamers for use in clinical and biomedical research.
\end{abstract}

\section{Background}

In recent years, small RNAs, including siRNAs (small interfering RNAs), shRNAs (small hairpin RNAs), aptamers, and ribozymes [1-9] have attracted increasing interest for their fundamental role in gene regulation, as well as for the potential of their use as novel diagnostic and therapeutic agents [10-16]. Interfering RNAs have generated particular interest due to its ability to effectively silence genes. For example, large-scale RNAi screens have been conducted to identify important

\footnotetext{
* Correspondence: fox@uh.edu

'Department of Biology and Biochemistry, University of Houston, Houston, TX, USA

Full list of author information is available at the end of the article
}

genes in various biological pathways [17]. Multiple siRNA-based therapies are currently under development and soon may be used in the treatment of diseases such as hepatitis virus infection, macular degeneration, leukemia, and acquired immune deficiency syndrome [18-21]. Likewise, due to their high affinity and relatively low cost, aptamers have been used in numerous investigations seeking novel diagnostic tools or new drugs [7,22-25]. For example, an anticoagulant RNA aptamer that specifically binds and inactivates Factor IXa, is currently in Phase II clinical trials [23,26]. With the expanding use of small RNAs in basic and applied biological research, the demand for large quantities of synthetic RNAs of high quality has dramatically increased.

\section{Biomed Central}


Traditional methods of chemical and enzymatic synthesis are effective but are currently very expensive when large amounts are needed. Thus, a cost-effective method to produce defined small RNAs in large quantities is urgently needed.

The in vivo expression of recombinant RNAs has been described for some time [27-29]. However, the heterogeneity of the RNA products and their instability in the cytoplasm due to cleavage by cellular ribonucleases (RNases) have made the process inefficient. For example, mRNAs expressed in E. coli from T7 promoter exhibit a substantial heterogeneity due to ambiguous termination of the RNA transcripts $[28,29]$. Attempts to obtain in vivo expression of aptamers also were not successful, apparently because the resulting transcripts were again heterogeneous and did not accumulate to any substantial level [30]. One way to overcome these limitations is by expressing RNA molecules of interest in a tRNA scaffold $[30,31]$. In one such study, the epsilon sequence of human hepatitis B virus (HBV) was inserted into cloning sites surrounded by a tRNA ${ }^{\text {Lys }}$ or tRNA ${ }^{\text {Met }}$ scaffold under the control of E. coli lpp promoter. The tRNA scaffold formed a structure that protected the RNA insert from nucleolytic digestion. The tRNA-HBV chimera was shown to be successfully expressed in E. coli and could be extracted by affinity capture when the chimeric RNA contained in addition a sephadex or streptavidin aptamer module. The RNA insert was released from the tRNA scaffold using the enzyme RNase $\mathrm{H}$ and two unmodified guide deoxyoligonucleotides. However, the reported absolute positional specificity of RNA cleavage by RNase $\mathrm{H}$ is uncommon under the described conditions [32-34], and cannot be regarded as a general case. In addition, it is not yet known if a large variety of RNAs can be successfully prepared with this system or how the presence of the construct may affect the host cell.

Herein, a fermentation-based system for expressing and purifying functional RNAs, especially RNAs of less than 100 nucleotides, is described. In this system, RNA sequences of interest are expressed under the strong P1 and $\mathrm{P} 2$ ribosomal promoters from the E. coli rrn $\mathrm{B}$ operon in the context of a carrier derived from $5 \mathrm{~S}$ rRNA [35]. The resulting RNA product does not enter the ribosome but nevertheless accumulates to levels comparable to those of wild type 5S rRNA. In previous work with this system, various RNA insert sequences were incorporated into the plasmid-encoded 5S rRNA scaffold [36,37]. In each case, the expressed RNA/insert chimeras accumulated to high levels in the cell. An examination of the transcriptome revealed that the presence of the insert had essentially no effect on gene expression in the host cell [38]. In order for this approach to be broadly applicable, however, it will be necessary to extract the RNA of interest from the $5 \mathrm{~S}$
rRNA carrier. We demonstrate herein that this can be effectively accomplished using sequence-specific DNAzymes [39-43]. An RNA substrate known as the $3 \times$ pen aRNA [37] (Figure 1) is used as a model system. The insert in this case is highly structured, as are many of the RNAs of interest and, at 71 nucleotides, illustrates that relatively large RNAs can be expressed in the $5 \mathrm{~S}$ rRNA carrier system with good success.

\section{Methods \\ Chemicals}

Enzymes were purchased from Promega (Madison, WI) or New England Biolabs (Ipswich, MA). Synthetic deoxyoligonucleotides (Table 1) were obtained from Eurofins MWG (Huntsville, AL) and IDT (Coralville, IA). DNA markers were purchased from NEB and Bionexus (Oakland, CA). Chemicals were obtained from Sigma (St. Louis, MO) and EMD Chemicals (Gibbstown, NJ).

\section{RNA expression scaffold}

Plasmid pCP3 $\times 3$ [37] was electroporated into E. coli JM109 (DE3) (Promega) and used as the RNA expression scaffold in this work. The core element of the plasmid is the truncated 5S rRNA gene from Vibrio proteolyticus with a 71-nt insertion sequence. Gene expression is controlled by the E. coli $r r n B$ P1 and P2 promoters. $3 \times$ pen aRNA coding sequence is followed by the E. coli rrnB T1 and T2 transcription terminators.

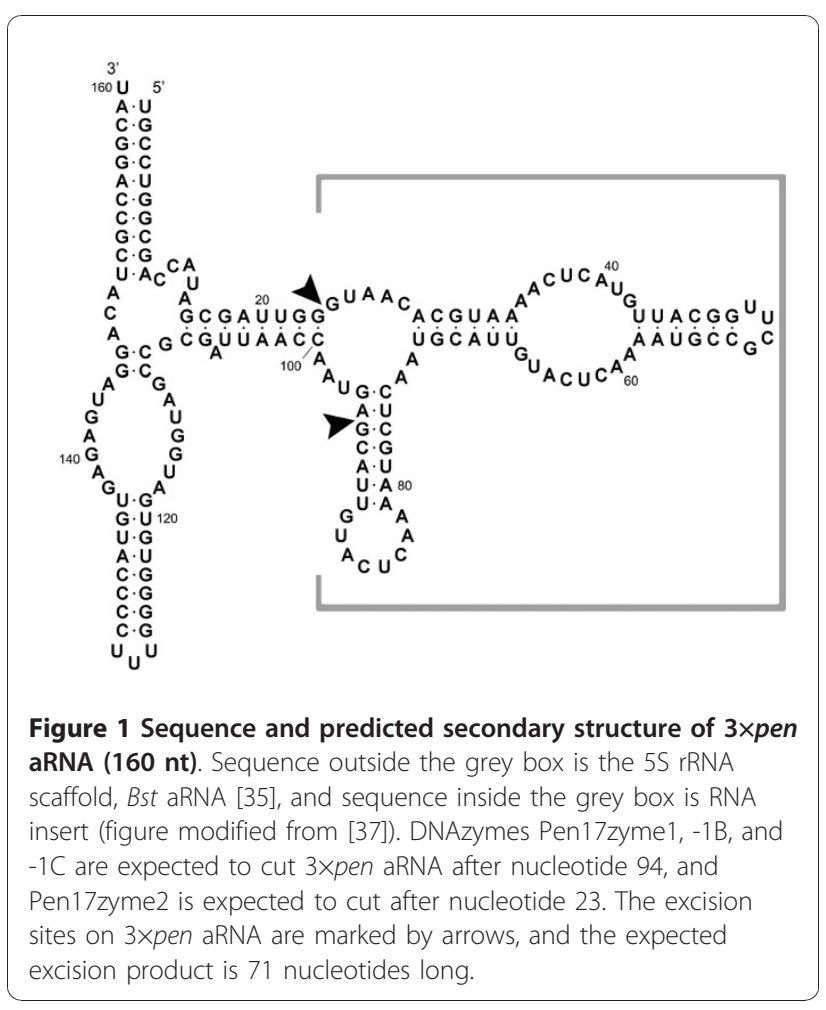


Table 1 Sequences and modifications of deoxyoligonucleotides used in this study

\begin{tabular}{lll}
\hline Name of oligos & Sequence (from $\mathbf{5}$ ' to $\mathbf{3}^{\prime}$ ) & Length (nt) \\
\hline Pen17zyme1 & CGCTAATTGGTTATCCGACCGGTCGAACGTAACATGAGTT & 41 \\
\hline Pen17zyme1B & GCTAATTGGTTACTGTCAGCGACACGAAGTAACATGAGTTTTAC & 44 \\
\hline Pen17zyme1C & CGCTAATTGGTTAGTCAGCTGACTCGAACGTAACATGAGTTTTAC & 45 \\
\hline Pen17zyme2 & GAGTTTTACGTGTTATGTCAGCGACACGAACAATCGCTATGGTC & 44 \\
\hline bioPEN17zyme1B & Biotin-GCTAATTGGTTACTGTCAGCGACACGAAGTAACATGAGTTTTAC & 44 \\
\hline bioPEN17zyme2 & Biotin-GAGTTTTACGTGTTATGTCAGCGACACGAACAATCGCTATGGTC & 44 \\
\hline bioantiPEN & Biotin-GAGTTTTACGAGTTACGTAACATGAGTTTTAC & 32
\end{tabular}

Underlined bold letters indicate residues that comprise the catalytic core of each DNAzyme.

\section{Isolation of small RNAs from E. coli}

Cells were grown at $37^{\circ} \mathrm{C}$ in $\mathrm{LB}$ medium with constant shaking (250 rpm). $100 \mu \mathrm{g} / \mathrm{ml}$ ampicillin was added to plasmid-carrying cells. Cell growth $\left(\mathrm{OD}_{600}\right)$ was monitored using a Labomed Spectro SC spectrophometer. After incubation, cells were collected by centrifugation $\left(30 \mathrm{~min}, 5000 \times \mathrm{g}, 4^{\circ} \mathrm{C}\right)$. The resulting (typically $200 \mathrm{mg}$ ) pellet was resuspended in $960 \mu \mathrm{l}$ of $10 \mathrm{mM}$ Tris- $\mathrm{HCl}$ ( $\mathrm{pH}$ 7.5). Cells were lysed by adding $160 \mu \mathrm{l}$ of $1 \mathrm{M}$ Tris-Acetate with $0.1 \mathrm{M}$ EDTA (pH 7.5), $160 \mu \mathrm{l}$ of $10 \% \mathrm{SDS}$ and $320 \mu \mathrm{l}$ of pure formamide. After $20 \mathrm{~min}$ shaking at $37^{\circ} \mathrm{C}, 1.6 \mathrm{ml}$ of $3 \mathrm{M}$ potassium acetate $(\mathrm{pH}$ 4.8) was added, and the mixture was shaken gently for another $10 \mathrm{~min}$. Cell debris and precipitated material were removed by centrifugation $\left(20 \mathrm{~min}, 10000 \times \mathrm{g}, 4^{\circ}\right.$ C). The cleared supernatant was recovered and mixed with $8 \mathrm{ml}$ of ethanol. After $1 \mathrm{~h}$ incubation at $-80^{\circ} \mathrm{C}$, the precipitated nucleic acids were collected by centrifugation $\left(20 \mathrm{~min}, 10000 \times \mathrm{g}, 4^{\circ} \mathrm{C}\right)$. The pellet was then resuspended in $300 \mu \mathrm{l}$ of $3 \mathrm{M}$ sodium acetate ( $\mathrm{pH} 5.0$ ), and was shaken at $37^{\circ} \mathrm{C}$ for $10 \mathrm{~min}$ to selectively solubilize the small RNAs. Insoluble material was removed by centrifugation $\left(20 \mathrm{~min}, 10000 \times \mathrm{g}, 4^{\circ} \mathrm{C}\right)$, and the supernatant was mixed with $750 \mu \mathrm{l}$ of ethanol. Finally, the precipitate containing mostly small RNAs was collected by centrifugation $\left(20 \mathrm{~min}, 10000 \times \mathrm{g}, 4^{\circ} \mathrm{C}\right)$, washed twice with $70 \%$ ethanol, and air dried for $15 \mathrm{~min}$.

RNA samples were analyzed by gel electrophoresis and staining as previously described $[44,45]$. Low Molecular Weight DNA Ladder (New England Biolabs, Ipswich, MA) was used as molecular weight standards. The ratio of $3 \times$ pen aRNA accumulation level to that of $5 \mathrm{~S}$ rRNA was determined using the freely available software package, ImageJ [46].

\section{Preparative PAGE}

The $3 \times$ pen aRNA was purified to homogeneity by electrophoresis on an $8 \%$ preparative denaturing polyacrylamide gel. After separation, RNA bands were visualized by UV shadowing over Silica F254 TLC plates (Whatman), and excised using a sterile blade. RNA was eluted from gel slices by triple extraction with equal volumes of $50 \mathrm{mM}$ HEPES- $\mathrm{NaOH}(\mathrm{pH}$ 7.5), 1 mM EDTA, $150 \mathrm{mM} \mathrm{NaCl}, 19.2 \mathrm{M}$ formamide. RNA was precipitated from the collected extracts by mixing with $0.1 \mathrm{vol}$. $3 \mathrm{M}$ sodium acetate ( $\mathrm{pH} \mathrm{5.0)}$ and 2.5 vol. ethanol. The sample was centrifuged $\left(20 \mathrm{~min}, 10000 \times \mathrm{g}, 4^{\circ} \mathrm{C}\right)$, the collected precipitate was washed twice with $70 \%$ ethanol, and air dried for 15 min. Dry RNA pellets were dissolved in water, and their concentration was determined spectrophotometrically.

\section{Cleavage with DNAzymes}

The DNAzymes used for the excision of RNA fragments from the 5S rRNA scaffold are listed in Table 1. The reaction conditions screened during optimization of $3 \times$ pen aRNA cleavage are summarized in Table 2. DNAzymes were annealed to the $3 \times$ pen aRNA substrate in $50 \mathrm{mM}$ MOPS- $\mathrm{NaOH}(\mathrm{pH} 7.2)$ containing additional components as specified in Table 2, at $90^{\circ} \mathrm{C}$ for $2 \mathrm{~min}$, and then cooled to $23^{\circ} \mathrm{C}$ over $10 \mathrm{~min}$ in a thermal cycler (Eurofins-MWG). After annealing, the mixture of DNAzymes and aRNA was adjusted to contain $125 \mathrm{mM} \mathrm{KCl}$, $500 \mathrm{mM} \mathrm{NaCl}, 7.5 \mathrm{mM} \mathrm{MgCl} 2, \mathrm{MnCl}_{2}$ (up to $45 \mathrm{mM}$ ), and $50 \mathrm{mM}$ MOPS (pH 7.2) besides the indicated additional components, and incubated at $23^{\circ} \mathrm{C}$ or $40^{\circ} \mathrm{C}$ for up to 72 hours. In reaction 16 and 23, 50 and 6 additional cycles were introduced, respectively. After the incubation, the reaction was terminated by adding 0.1 vol. $3 \mathrm{M}$ sodium acetate ( $\mathrm{pH}$ 5.0). The reaction products were recovered by ethanol precipitation and analyzed by denaturing PAGE. The intensity of bands in these reactions was plotted using the 'profile' function of ImageJ [46], and the total cutting percentage was quantified as $\mathrm{P}=1$ - [intact $3 \times$ pen aRNA]/[total $3 \times$ pen aRNA]. Similarly, ImageJ was used to determine the yield of final product relative to the starting amount of chimeric aRNA per wet cell paste.

\section{Isolation of 5'-biotinylated DNAzymes and RNA Fragments by Affinity Capture}

Biotinylated DNAzymes were removed from the mixture of cleavage reaction products using streptavidin agarose beads (Molecular Probes, Eugene, OR) in $3 \times$ NTE buffer 
Table 2 Conditions of $3 \times$ pen aRNA cleavage evaluated during optimization of the reaction yield

\begin{tabular}{|c|c|c|c|c|c|c|c|}
\hline $\begin{array}{l}\text { Reaction } \\
\text { No. }\end{array}$ & $\begin{array}{c}\text { [3×pen } \\
\text { aRNA] } \\
(\mu \mathrm{M})^{*}\end{array}$ & $\begin{array}{c}\text { Molar ratio 3xpen aRNA: Pen17zyme1/1B/1C: } \\
\text { Pen17zyme2 }\end{array}$ & $\begin{array}{c}\text { Additional } \\
\text { components } \\
\text { in the annealing } \\
\text { buffer }\end{array}$ & $\begin{array}{l}{\left[\mathrm{Mn}^{2+}\right]} \\
(\mathrm{mM})^{*}\end{array}$ & $\begin{array}{l}\text { Reaction } \\
\mathrm{T}\left({ }^{\circ} \mathrm{C}\right)\end{array}$ & Time & $\begin{array}{l}\text { Additional } \\
\text { Cycles }\end{array}$ \\
\hline 1 & 0.25 & 1:0:1 & N/A & 0 & 23 & $\begin{array}{c}10 \\
\min \end{array}$ & 0 \\
\hline 2 & 0.25 & 1:0:1 & $\mathrm{N} / \mathrm{A}$ & 7.5 & 23 & $\begin{array}{l}10 \\
\min \end{array}$ & 0 \\
\hline 3 & 0.25 & 1:0:1 & N/A & 15 & 23 & $\begin{array}{l}10 \\
\min \end{array}$ & 0 \\
\hline 4 & 0.25 & 1:0:1 & N/A & 45 & 23 & $\begin{array}{c}10 \\
\min \end{array}$ & 0 \\
\hline 5 & 0.25 & 1:0:1 & N/A & 15 & 23 & $\begin{array}{l}100 \\
\min \end{array}$ & 0 \\
\hline 6 & 0.25 & 1:1(Pen17zyme1):0 & N/A & 15 & 23 & $\begin{array}{l}100 \\
\min \end{array}$ & 0 \\
\hline 7 & 0.25 & 1:1(Pen17zyme1B):0 & N/A & 15 & 23 & $\begin{array}{l}100 \\
\min \end{array}$ & 0 \\
\hline 8 & 0.25 & 1:1(Pen17zyme1C):0 & N/A & 15 & 23 & $\begin{array}{l}100 \\
\min \end{array}$ & 0 \\
\hline 9 & 0.25 & 1:5(Pen17zyme1B):0 & N/A & 15 & 23 & $\begin{array}{l}100 \\
\min \end{array}$ & 0 \\
\hline 10 & 0.25 & 1:1(Pen17zyme1B):0 & $\mathrm{N} / \mathrm{A}$ & 15 & 23 & $17 \mathrm{~h}$ & 0 \\
\hline 11 & 0.25 & 1:1(Pen17zyme1B):0 & N/A & 15 & 40 & $\begin{array}{l}100 \\
\min \end{array}$ & 0 \\
\hline 12 & 0.25 & 1:1(Pen17zyme1B):0 & $10 \% \mathrm{EtOH}$ & 15 & 23 & $\begin{array}{l}100 \\
\min \end{array}$ & 0 \\
\hline 13 & 0.25 & 1:5(Pen17zyme1B):0 & $\begin{array}{c}0.3 \mathrm{M} \mathrm{KCl}, 1.2 \mathrm{M} \\
\mathrm{NaCl}\end{array}$ & 15 & 23 & $17 \mathrm{~h}$ & 0 \\
\hline 14 & 0.25 & 1:5(Pen17zyme1B):0 & 20\% PEG 8000 & 15 & 23 & $17 \mathrm{~h}$ & 0 \\
\hline 15 & 0.25 & 1:5(Pen17zyme1B):0 & $500 \mu \mathrm{M}$ spermine & 15 & 23 & $17 \mathrm{~h}$ & 0 \\
\hline 16 & 0.25 & 1:5(Pen17zyme1B):0 & N/A & 15 & 23 & $17 \mathrm{~h}$ & 50 \\
\hline 17 & 0.25 & 1:5(Pen17zyme1B):0 & $\begin{array}{l}2.2 \mathrm{M} \text { potassium } \\
\text { acetate }\end{array}$ & 15 & 23 & $17 \mathrm{~h}$ & 0 \\
\hline 18 & 0.25 & 1:5(Pen17zyme1B):0 & $3 \mathrm{M} \mathrm{LiCl}$ & 15 & 23 & $17 \mathrm{~h}$ & 0 \\
\hline 19 & 0.80 & 1:1(Pen17zyme1B):1 & $500 \mu \mathrm{M}$ spermine & 15 & 23 & $17 \mathrm{~h}$ & 0 \\
\hline 20 & 0.80 & 1:10(Pen17zyme1B):1 & $500 \mu \mathrm{M}$ spermine & 15 & 23 & $17 \mathrm{~h}$ & 0 \\
\hline 21 & 0.80 & 1:20(Pen17zyme1B):2 & $500 \mu \mathrm{M}$ spermine & 15 & 23 & $17 \mathrm{~h}$ & 0 \\
\hline 22 & 0.80 & 1:10(Pen17zyme1B):10 & $500 \mu \mathrm{M}$ spermine & 15 & 23 & $17 \mathrm{~h}$ & 0 \\
\hline 23 & 0.80 & 1:10(Pen17zyme1B):10 & $500 \mu \mathrm{M}$ spermine & 15 & 23 & $17 \mathrm{~h}$ & 6 \\
\hline 24 & 0.80 & 1:10(Pen17zyme1B):10 & $500 \mu \mathrm{M}$ spermine & 15 & 23 & $40 \mathrm{~h}$ & 0 \\
\hline 25 & 0.80 & 1:10(Pen17zyme1B):10 & $500 \mu \mathrm{M}$ spermine & 15 & 23 & $72 \mathrm{~h}$ & 0 \\
\hline 26 & 0.80 & 1:10(bioPen17zyme1B):10(biopen17zyme2) & $500 \mu \mathrm{M}$ spermine & 15 & 23 & $72 \mathrm{~h}$ & 0 \\
\hline
\end{tabular}

* The value corresponds to the final concentration of the indicated component in the reaction mixture.

(0.6 M NaCl, 15 mM Tris- $\mathrm{HCl}, 7.5$ mM EDTA, pH 7.5) [47]. The DNAzymes were recovered from the beads by heating in $\mathrm{H}_{2} \mathrm{O}$ at $65^{\circ} \mathrm{C}$. The excised RNA fragments were isolated by affinity capture through hybridization to a complementary oligodeoxyribonucleotide, bioantiPEN (Table 1), immobilized on streptavidin agarose beads via streptavidin-biotin linkage [47].

\section{Results and Discussion}

\section{Expression of 3xpen aRNA in strain JM109 (DE3)}

The 160-nt $3 \times$ pen aRNA was strongly expressed in E. coli (Figure 2 and Figure 3A, Lane 1). The ratio of $3 \times$ pen aRNA to $5 \mathrm{~S}$ rRNA after 8 and 24 h of incubation was 1.07 and 0.46 , respectively, as determined by electrophoresis and imaging as described above. Thus, the 


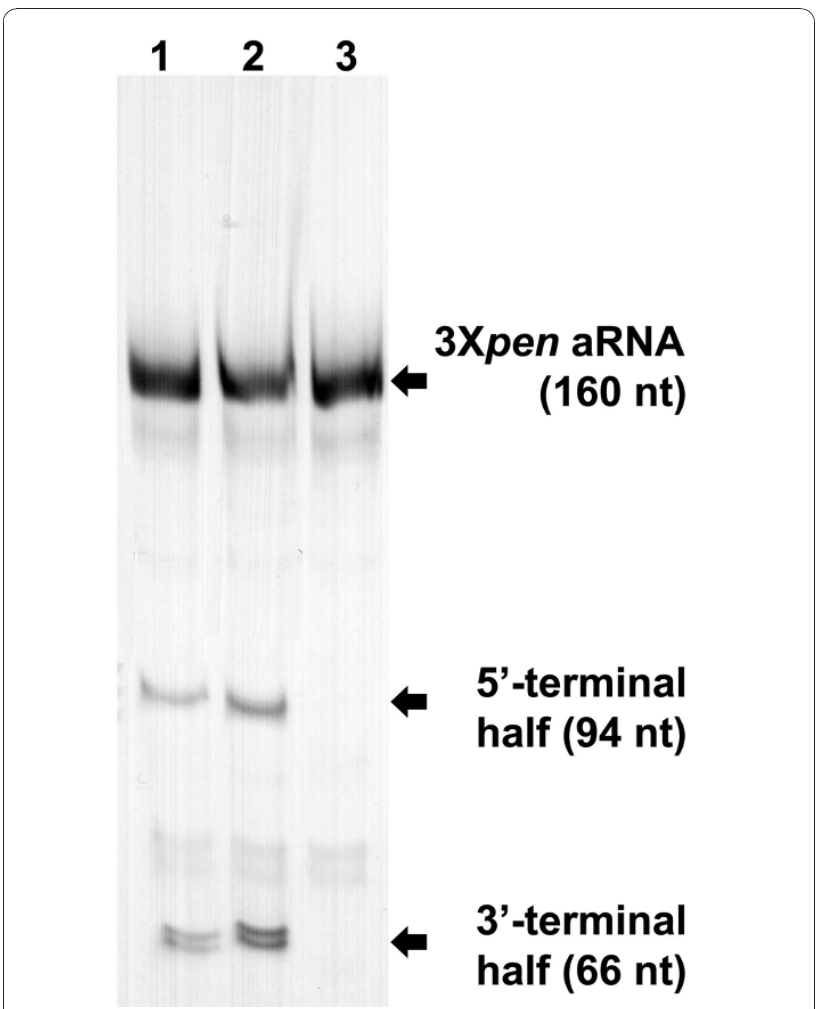

Figure $23 \times$ pen aRNA cleavage by Pen17zyme1, Pen17zyme1B or Pen17zyme1C. Cleavage reaction products were analyzed on denaturing 8\% PAGE. The expected cleavage products are 94-nt 5' terminal and 66-nt $3^{\prime}$ terminal halves of 160-nt 3xpen aRNA. Lane 1, 3xpen aRNA cleavage with Pen17zyme1; Lane 2, 3xpen aRNA cleavage with Pen17zyme1B; Lane 3, 3xpen aRNA cleavage with Pen17zyme 1C. Cleavage reactions were set up as follows: RNA substrate and indicated DNAzyme were annealed in $50 \mathrm{mM}$ MOPS$\mathrm{NaOH}\left(\mathrm{pH}\right.$ 7.2), $500 \mu \mathrm{M}$ spermine by incubating the mixture at $90^{\circ} \mathrm{C}$ for 2 min followed by cooling to $23^{\circ} \mathrm{C}$ within $10 \mathrm{~min}$. After annealing, the composition of the mixture was adjusted to $125 \mathrm{mM}$ $\mathrm{KCl}, 500 \mathrm{mM} \mathrm{NaCl}, 7.5 \mathrm{mM} \mathrm{MgCl} 2,15 \mathrm{mM} \mathrm{MnCl}$, $150 \mu \mathrm{M}$ spermine, and $50 \mathrm{mM}$ MOPS-NaOH (pH 7.2), with 3xpen aRNA: DNAzyme molar ratio 1: 5 . The reaction was performed at $23^{\circ} \mathrm{C}$ for 16 hours, and stopped by ethanol precipitation of the products.

accumulation of 3xpen aRNA after an 8-hour incubation slightly exceeded that of native $5 \mathrm{~S}$ rRNA but subsequently declined, suggesting selective degradation of the recombinant RNA over time. Isolation of $3 \times$ pen aRNA from 8-hour bacterial cultures routinely yielded $2.5-2.6$ $\mathrm{mg}$ of the chimeric RNA from $1 \mathrm{~g}$ of wet cells.

\section{Excision of specific small RNA using DNAzymes}

In order to optimize the cleavage reaction, multiple reaction conditions were examined (Table 2 ) by varying DNAzymes, RNA substrate to DNAzymes ratio, additives, $\mathrm{Mn}^{2+}$ concentration, reaction temperature, and incubation time. In some cases, alternating denaturation and renaturation cycles were introduced to examine whether this increased the overall yield of the desired
RNA products. Equal amounts of $3 \times$ pen aRNA were used in each reaction condition, and the reaction products were analyzed by denaturing PAGE. Four DNAzymes (Pen17zyme1, $-1 \mathrm{~B},-1 \mathrm{C}$ and -2) were investigated for their ability to excise small RNAs from the 5S rRNA expression scaffold. Their predicted excision sites on the $3 \times$ pen aRNA are shown in Figure 1, and cleavage at these two sites was expected to produce a 71-nt product. As revealed by electrophoresis, the overall yield of the desired RNA products was higher with Pen17zyme1B than with Pen17zyme1, while Pen17zyme1C was found to be inactive (Figure 2). Thus, Pen17zyme1B, which cleaves GA dinucleotides, and Pen17zyme2, which cleaves GG dinucleotides (Figure 1), were used in subsequent cleavage reactions. Additionally, the 5'-biotinylated DNAzymes were found to cleave with equal efficiency as their unmodified forms, and the expected 71-nt product was obtained likewise by cleavage reactions using 5'-biotinylated bioPen 17 zyme1B and bioPen17zyme2 (Figure 4, Lane 3). Intensity of the $3 \times$ pen aRNA band on the polyacrylamide gel (Figure 3) decreased when the concentration of Pen17zyme1B and Pen17zyme2 increased in the reaction mixtures, indicating that $3 \times$ pen aRNA was being efficiently cleaved by these DNAzymes. Complete excision was achieved after $72 \mathrm{~h}$ incubation at $23^{\circ} \mathrm{C}$ and a molar ratio of [ $3 \times p e n$ aRNA]: [Pen17zyme1B]: [Pen17zyme2] of 1:10:10 (Table 3).

In most cases, the presence of additional components in the annealing buffer including ethanol, PEG 8000, potassium acetate, $\mathrm{LiCl}$ and increased concentrations of $\mathrm{KCl}$ or $\mathrm{NaCl}$ did not affect the overall yield of the desired RNA product. However, the addition of $500 \mu \mathrm{M}$ spermine improved the total cutting percentage significantly. It is thought that the spermine may stabilize the DNAzyme/RNA hybrids [48]. Spermine-mediated stabilization of DNA helices [49] and DNA-RNA hybrids $[50,51]$ has been extensively reported in the literature. Previous studies of DNAzymes have shown that substrate cleavage required divalent metal cations such as $\mathrm{Mg}^{2+}, \mathrm{Ca}^{2+}$ or $\mathrm{Mn}^{2+}$ [52-55]. Here, the effects of four different $\mathrm{Mn}^{2+}$ conditions $(0,7.5,15$ and $45 \mathrm{mM})$ were tested. We confirmed that in the absence of $\mathrm{Mn}^{2+}$, essentially no cleavage was seen and that the highest total cutting percentage was observed at $15 \mathrm{mM} \mathrm{Mn}^{2+}$. With respect to the reaction temperature, it was found that $23^{\circ} \mathrm{C}$ was superior to $40^{\circ} \mathrm{C}$ in producing efficient RNA processing (data not shown). Introducing denaturation/renaturation cycles into the reaction did not improve the overall yield of the desired RNA products. Perhaps not surprisingly, it was also found that longer incubation time greatly improved the total cutting percentage when the same concentration of DNAzymes was added in the reaction mixture (Table 3 ). 


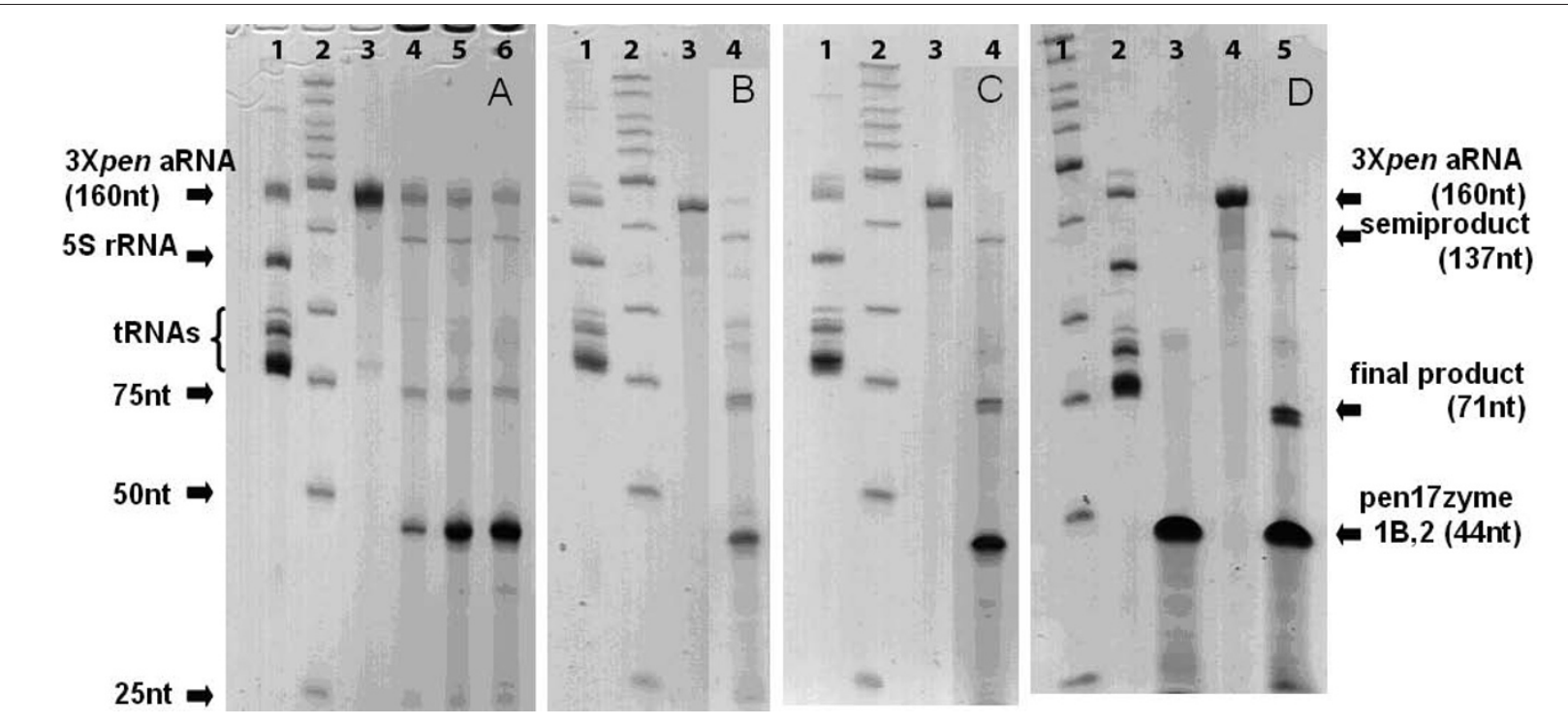

Figure $33 \times$ pen aRNA cleavage by Pen17zyme1B and Pen17zyme2. Cleavage reaction products were analyzed on denaturing $8 \%$ PAGE. Incubation of 3xpen aRNA (160 nt) with the Pen17zyme1B and Pen17zyme2 resulted in accumulation of 71-nt final excision product and 137-nt semi-product. (A) Lane 1, total RNA from E. coli JM109(DE3)/pCP3×3 enriched for low molecular weight RNAs (total RNA); Lane 2, low molecular weight DNA ladder (LWM); Lane 3, 3xpen aRNA; Lanes 4-6, Cleavage products of 3xpen aRNA after 17 hours of incubation with 3xpen aRNA: Pen17zyme1B: Pen17zyme2 molar ratio 1:1:1, 1:10:1, and 1:10:2, respectively. (B) Lane 1, total RNA; Lane 2, LWM; Lane 3, 3xpen aRNA; Lane 4, Cleavage products of $3 \times$ pen aRNA after 40 hours of incubation with 3xpen aRNA: Pen17zyme1B: Pen17zyme2 molar ratio 1:10:1. (C): Lane 1, total RNA; Lane 2, LWM; Lane 3, 3xpen aRNA; Lane 4, Cleavage products of 3xpen aRNA after 40 hours of incubation with 3xpen aRNA: Pen17zyme1B: Pen17zyme2 molar ratio 1:10:10. (D): Lane 1, LWM; Lane 2, total RNA; Lane 3, equimolar mixture of Pen17zyme1B and Pen17zyme2; Lane 4, 3xpen aRNA; Lane 5, Cleavage products of 3xpen aRNA after 72 hours of incubation with 3xpen aRNA: Pen17zyme1B: Pen17zyme2 molar ratio 1:10:10. Cleavage reactions were performed under conditions described in legend to Figure 2 except for the incubation time and $3 \times p e n$ aRNA: DNazymes molar ratio, which were as indicated above.

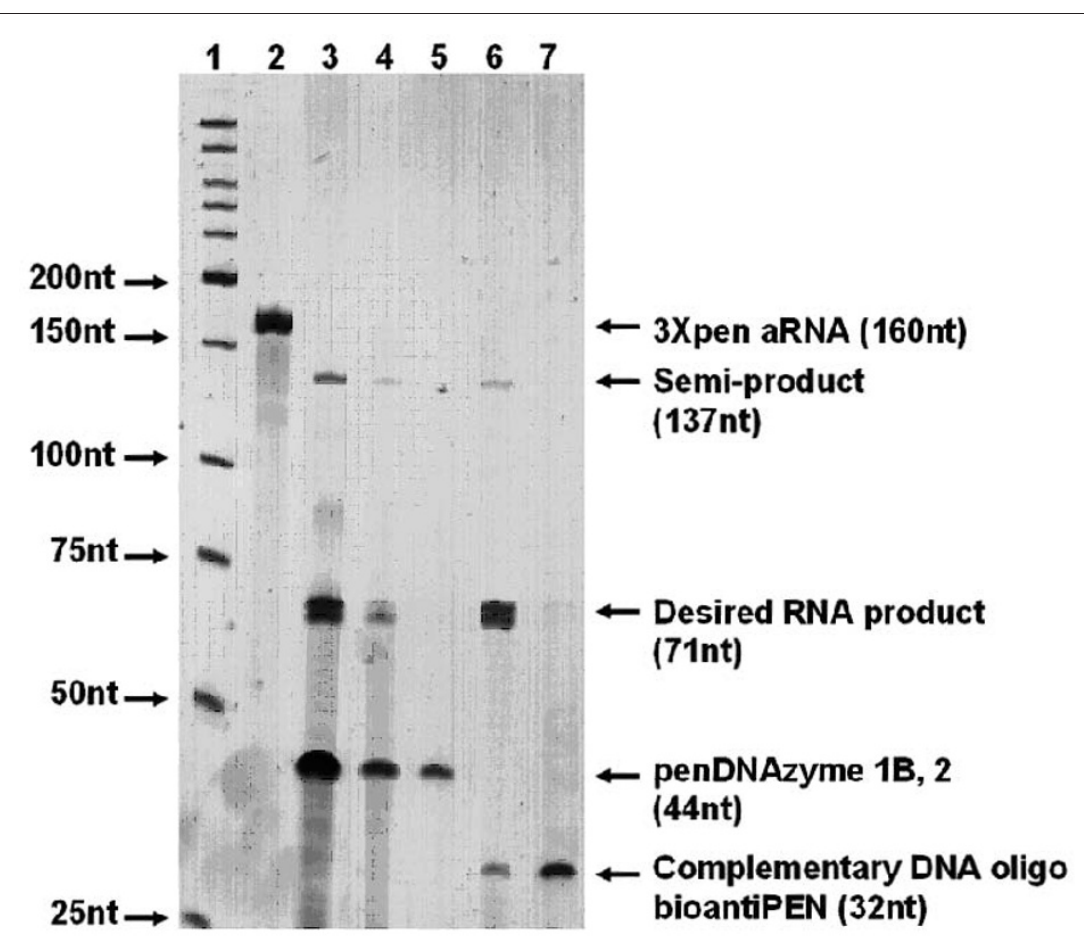

Figure 4 Separation of the products of 3xpen aRNA cleavage using streptavidin agarose beads. Collected fractions were analyzed on denaturing 8\% PAGE. Lane1, LWM; Lane 2, 3xpen aRNA; Lane 3, Original cleavage reaction mixture; Lanes 4-5: Isolation of biotinylated DNAzymes, first and second elutions from the beads, respectively; Lane 6: Isolation of 71-nt excision product on the beads saturated with biotinylated complementary deoxyoligonucleotide, bioantiPEN; Lane 7: Recovery of bioantiPEN from the beads. Cleavage reaction was performed for 72 hours under conditions described in legend to Figure 2, with 3xpen aRNA: bioPen17zyme1B: bioPen17zyme2 molar ratio 1:10:10. 
Table 3 Quantitative analysis of total cleavage percentage P of 3xpen aRNA by Pen17zyme1B and Pen17zyme2

\begin{tabular}{|c|c|c|c|c|}
\hline $\begin{array}{l}\text { Molar ratio of } 3 \times p e n \text { aRNA: } \\
\text { Pen17zyme1B: Pen17zyme2 }\end{array}$ & $\begin{array}{c}\text { Reaction } \\
\text { time } \\
\text { (hours) }\end{array}$ & $\begin{array}{l}\text { 71-nt final product yield related to } \\
\text { the initial 3xpen aRNA amount }\end{array}$ & $\begin{array}{l}\text { 137-nt semi-product yield related to } \\
\text { the initial } 3 \times \text { pen aRNA amount }\end{array}$ & $\begin{array}{c}\mathrm{P} \text { (Total } \\
\text { cleavage } \\
\text { percentage) }\end{array}$ \\
\hline $1: 1: 1$ & 17 & $30 \%$ & $15 \%$ & $45 \%$ \\
\hline $1: 10: 1$ & 17 & $39 \%$ & $16 \%$ & $55 \%$ \\
\hline $1: 10: 2$ & 17 & $42 \%$ & $15 \%$ & $57 \%$ \\
\hline $1: 10: 1$ & 40 & $70 \%$ & $22 \%$ & $92 \%$ \\
\hline $1: 10: 10$ & 40 & $77 \%$ & $23 \%$ & $100 \%$ \\
\hline $1: 10: 10$ & 72 & $90 \%$ & $10 \%$ & $100 \%$ \\
\hline
\end{tabular}

Cleavage reactions were performed under conditions described in legend to Figure 2 except for the reaction time and $3 \times p e n$ aRNA: DNazymes molar ratio, which were as indicated above.

In summary, the best conditions among those tested were as follows: $(i)$ a substrate to enzyme molar ratio ([3×pen aRNA]:[Pen17zyme1B]:[Pen17zyme2]) of 1:10:10, (ii) denaturation and annealing in $50 \mathrm{mM}$ MOPS- $\mathrm{NaOH}$ (pH 7.2), $500 \mu \mathrm{M}$ spermine at $90^{\circ} \mathrm{C}$ for 2 min with subsequent cooling to $23^{\circ} \mathrm{C}$ over a period of $10 \mathrm{~min}$, (iii) incubation in $125 \mathrm{mM} \mathrm{KCl}, 500 \mathrm{mM} \mathrm{NaCl}, 7.5 \mathrm{mM} \mathrm{MgCl}_{2}, 15$ $\mathrm{mM} \mathrm{MnCl}_{2}, 150 \mu \mathrm{M}$ spermine, and $50 \mathrm{mM}$ MOPS-NaOH (pH 7.2), at $23^{\circ} \mathrm{C}$ for $72 \mathrm{~h}$. As suggested by Table 3, longer incubation time is likely to further improve overall yield of the desired RNA fragment.

\section{RNA and DNAzyme Recovery by Affinity Capture}

It is desirable that the isolation of the RNA product and recovery of DNAzymes avoid labor-intensive procedures. Following the cleavage reaction, the 5'-biotinylated Pen17zymes 1B and -2 were successfully removed from the reaction mixture by affinity chromatography, heat eluted (Figure 4, lane $4 \& 5$ ) and could presumably be reused in new cleavage reactions. After removal of the DNAzymes, the reaction mixture was purified by hybridization affinity capture on an immobilized oligonucleotide bioantiPEN, which is complementary to the desired RNA product. Figure 4 illustrates that the RNA eluate from the affinity matrix contained the 71-nt excised RNA fragment, indicating the expected digestion of $3 \times$ pen aRNA. The RNA product was found to be $82 \%$ pure as determined by electrophoresis and imaging as described above. The overall yield of the purified RNA fragment was $0.72 \mathrm{mg}$ from $1 \mathrm{~g}$ of cells. However, trace amounts of deoxyoligonucleotide bioantiPEN were found in the RNA elution fraction (Figure 4, lane 6). If desired, this contamination could be easily removed by DNase treatment of the excised RNA fraction. Alternatively, this contamination could be prevented by covalent immobilization of the capture oligo on rigid supports like glass or silica.

\section{Conclusions}

The feasibility of an E. coli based in vivo expression system capable of producing small RNAs using a 5S rRNA scaffold has been demonstrated. The DNA construct is recognized as essentially a normal RNA coding region and the resulting transcript is processed into a single RNA species of defined sequence and length. The strong expression of chimeric $3 \times$ pen aRNA here and in nearly twenty other $5 \mathrm{~S}$ rRNA/insert chimeras examined in previous studies $[36,56]$ demonstrates that the $5 \mathrm{~S}$ rRNA scaffold is robust and can accommodate many RNA inserts of diverse sizes.

Here, we have also described a new method for total RNA isolation. Compared to traditional RNA isolation methods such as Trizol $^{\mathrm{Tm}}[57,58]$ or hot phenol extractions, the new method does not involve toxic chemicals. Thus, it is safer to the user, more environmentally friendly, and might be particularly advantageous for scale-up. The new method also displays some degree of desirable size selectivity, in that low molecular weight RNAs appeared to have been enriched, while the amount of larger RNAs had been reduced at the end of the RNA isolation procedure.

In addition, we demonstrated the successful excision of a 3×pen aRNA from the scaffold using 8-17 DNAzymes Pen17zyme1B and Pen17zyme2. Since DNAzymes can be readily obtained from various commercial sources, and the reaction preferentially occurs at room temperature $\left(23^{\circ} \mathrm{C}\right)$, it constitutes an attractive method for the large scale preparation of small RNAs through fermentation of $E$. coli. Under best reaction conditions, nearly all the $3 \times$ pen aRNA was digested, and $90 \%$ of it was further processed to yield the desired 71-nt RNA product after $72 \mathrm{~h}$. Depending on the requirements, the rate of cleavage can be manipulated by adjusting the DNAzyme-toRNA ratio to either speed up the process or conserve DNAzymes. In an industrial environment, the priority might be given to reducing the costs of reagents $v s$. the reaction rate. Manufacturing processes usually involve continuous operations, and under such circumstances the time for individual reaction cycles may not be as important as the cost for labor, chemicals, and equipment. 
In a further step towards improving the economical attractiveness of the method, we have shown recovery of both the RNA product and the DNAzymes through affinity chromatography. Although DNA oligomers can be chemically synthesized, the ability to readily recycle the DNAzymes will substantially reduce the cost of the whole procedure. In the present study, affinity chromatography of streptavidin agarose beads was employed to demonstrate the possibility of recovering DNAzymes. Future studies may include covalent immobilization of DNAzymes on more durable and less expensive supports such as glass or silica, which would be more compatible with industrial applications. In addition, it was shown that a longer incubation time greatly improved the overall yield of desired RNA product with equal concentration of DNAzymes in the reaction mixtures. Therefore, the cost of DNAzymes can be further reduced by trading off speed for cost.

In summary, a fermentation-based approach to large scale RNA production of functional RNAs using the $5 \mathrm{~S}$ rRNA scaffold strategy is described. The approach combines high levels of in vivo expression, convenient purification of chimeric RNAs and cost-efficient excision of insert RNA from the chimera and therefore offers a promising alternative for large scale RNA manufacturing.

\section{List of abbreviations}

RNA: ribonucleic acid; DNA: deoxyribonucleic acid; $5 S$ rRNA: $5 S$ ribosomal RNA; mRNA: messenger RNA; tRNA: transfer RNA; DNAzyme: deoxyribozyme; RNAi: RNA interference; PEG: polyethylene glycol; PAGE: polyacrylamide gel electrophoresis; UV: ultraviolet; TLC: thin-layer chromatography; EDTA: ethylenediaminetetraacetic acid; HEPES: N-2-hydroxyethylpiperazine-N'-2ethanesulfonic acid; MOPS: 3-(N-morpholino)propanesulfonic acid.

\section{Acknowledgements}

This work was funded in part by grants to GEF from the Georgia Institute of Technology Center for Ribosomal Evolution and Adaptation and the Center for Bionanotechnology and Environmental Research at Texas Southern University (NASA Cooperative Agreement NNX08B4A47A), to RCW from the Robert A. Welch Foundation (E-1264) and the STTR programs of the National Science Foundation (0738336) and National Institutes of Health

(1R41ES016478-01) to GWJ.

\section{Author details}

${ }^{1}$ Department of Biology and Biochemistry, University of Houston, Houston, TX, USA. '2Department of Chemical and Biomolecular Engineering, University of Houston, Houston, TX, USA. ${ }^{3}$ BioTex, Inc, Houston, TX, USA.

\section{Authors' contributions}

GEF, VGS and GWJ conceived the study. YL and VGS designed and performed the experiments. US, RCW, and GWJ participated in data analysis. All authors contributed to drafting the manuscript. All authors read and approved the final manuscript.

\section{Competing interests}

GEF, VGS, GWJ, and YL have one or more pending patent applications on the described technology. This intellectual property has been licensed to BioTex, Inc.

Received: 23 July 2010 Accepted: 6 December 2010 Published: 6 December 2010
References

1. Kaur G, Roy I: Therapeutic applications of aptamers. Expert Opin Investig Drugs 2008, 17:43-60

2. Pai SS, Ellington AD: Using RNA aptamers and the proximity ligation assay for the detection of cell surface antigens. Methods Mol Biol 2009, 504:385-398.

3. Lee C, Dhillon J, Wang MY, Gao Y, Hu K, Park E, Astanehe A, Hung MC, Eirew P, Eaves CJ, Dunn SE: Targeting YB-1 in HER-2 overexpressing breast cancer cells induces apoptosis via the mTOR/STAT3 pathway and suppresses tumor growth in mice. Cancer Res 2008, 68:8661-8666.

4. Chu TC, Twu KY, Ellington AD, Levy M: Aptamer mediated siRNA delivery. Nucleic Acids Res 2006, 34:e73.

5. Chalk AM, Warfinge RE, Georgii-Hemming P, Sonnhammer EL: siRNAdb: a database of siRNA sequences. Nucleic Acids Res 2005, , 33 Database: D131-134

6. Sefah K, Phillips JA, Xiong X, Meng L, Van Simaeys D, Chen H, Martin J, Tan W: Nucleic acid aptamers for biosensors and bio-analytical applications. Analyst 2009, 134:1765-1775.

7. Dausse E, Da Rocha Gomes S, Toulme JJ: Aptamers: a new class of oligonucleotides in the drug discovery pipeline? Curr Opin Pharmacol 2009, 9:602-607

8. Winkler WC, Nahvi A, Roth A, Collins JA, Breaker RR: Control of gene expression by a natural metabolite-responsive ribozyme. Nature 2004 428:281-286

9. Barrick JE, Corbino KA, Winkler WC, Nahvi A, Mandal M, Collins J, Lee M, Roth A, Sudarsan N, Jona I, Wickiser JK, Breaker RR: New RNA motifs suggest an expanded scope for riboswitches in bacterial genetic control. Proc Natl Acad Sci USA 2004, 101:6421-6426.

10. Kanzaki LI, Ornelas SS, Arganaraz ER: RNA interference and HIV-1 infection. Rev Med Virol 2008, 18:5-18

11. Lea MA: Recently identified and potential targets for colon cancer treatment. Future Oncol 2010, 6:993-1002.

12. Pfeffer S, Baumert TF: Impact of microRNAs for pathogenesis and treatment of hepatitis $C$ virus infection. Gastroenterol Clin Biol.

13. Thoma C, Bogner E: Short hairpin RNAs specific to human cytomegalovirus terminase subunit pUL89 prevent viral maturation. Antivir Ther 2010, 15:391-400.

14. Gebhardt K, Shokraei A, Babaie E, Lindqvist BH: RNA aptamers to Sadenosylhomocysteine: kinetic properties, divalent cation dependency, and comparison with anti-S-adenosylhomocysteine antibody. Biochemistry 2000, 39:7255-7265.

15. McCauley TG, Hamaguchi N, Stanton M: Aptamer-based biosensor arrays for detection and quantification of biological macromolecules. Anal Biochem 2003, 319:244-250.

16. Rajendran $M$, Ellington AD: Selecting nucleic acids for biosensor applications. Comb Chem High Throughput Screen 2002, 5:263-270.

17. Alekseev OM, Richardson RT, Alekseev O, O'Rand MG: Analysis of gene expression profiles in HeLa cells in response to overexpression or siRNAmediated depletion of NASP. Reprod Biol Endocrinol 2009, 7:45.

18. Capodici J, Kariko K, Weissman D: Inhibition of HIV-1 infection by small interfering RNA-mediated RNA interference. J Immunol 2002, 169:5196-5201.

19. Coemans B, Takahashi $Y$, Berberich $T$, Ito A, Kanzaki H, Matsumura H, Saitoh H, Tsuda S, Kamoun S, Sagi L, Swennen R, Terauchi R: Highthroughput in planta expression screening identifies an ADP-ribosylation factor (ARF1) involved in non-host resistance and $R$ gene-mediated resistance. Mol Plant Pathol 2008, 9:25-36.

20. Wei L, Liu X, Cao C: [RNA interference and its application in inhibiting HIV-1 infection]. Sheng Wu Gong Cheng Xue Bao 2005, 21:516-519.

21. Sagan SM, Nasheri N, Luebbert C, Pezacki JP: The efficacy of siRNAs against hepatitis $C$ virus is strongly influenced by structure and target site accessibility. Chem Biol 2010, 17:515-527.

22. Majumder P, Gomes KN, Ulrich H: Aptamers: from bench side research towards patented molecules with therapeutic applications. Expert Opin Ther Pat 2009, 19:1603-1613.

23. Rusconi CP, Roberts JD, Pitoc GA, Nimjee SM, White RR, Quick G, Scardino E, Fay WP, Sullenger BA: Antidote-mediated control of an anticoagulant aptamer in vivo. Nat Biotechnol 2004, 22:1423-1428.

24. Mi J, Zhang X, Rabbani ZN, Liu Y, Reddy SK, Su Z, Salahuddin FK, Viles K, Giangrande PH, Dewhirst MW, Sullenger BA, Kontos CD, Clary BM: RNA 
aptamer-targeted inhibition of NF-kappa B suppresses non-small cell lung cancer resistance to doxorubicin. Mol Ther 2008, 16:66-73.

25. Sarraf-Yazdi S, Mi J, Moeller BJ, Niu X, White RR, Kontos CD, Sullenger BA, Dewhirst MW, Clary BM: Inhibition of in vivo tumor angiogenesis and growth via systemic delivery of an angiopoietin 2-specific RNA aptamer. J Surg Res 2008, 146:16-23.

26. Chan MY, Cohen MG, Dyke CK, Myles SK, Aberle LG, Lin M, Walder J, Steinhubl SR, Gilchrist IC, Kleiman NS, Vorchheimer DA, Chronos N, Melloni C, Alexander JH, Harrington RA, Tonkens RM, Becker RC, Rusconi CP: Phase $1 \mathrm{~b}$ randomized study of antidote-controlled modulation of factor IXa activity in patients with stable coronary artery disease. Circulation 2008, 117:2865-2874

27. Lago BD, Birnbaum J, Demain AL: Fermentation process for doublestranded ribonucleic acid, an interferon inducer. Appl Microbiol 1972, 24:430-436.

28. Studier FW, Rosenberg AH, Dunn JJ, Dubendorff JW: Use of T7 RNA polymerase to direct expression of cloned genes. Methods Enzymol 1990, 185:60-89.

29. Lopez PJ, Dreyfus M: The lacZ mRNA can be stabilised by the T7 late mRNA leader in E. coli. Biochimie 1996, 78:408-415.

30. Ponchon L, Dardel F: Recombinant RNA technology: the tRNA scaffold. Nat Methods 2007, 4:571-576.

31. Ponchon L, Beauvais G, Nonin-Lecomte S, Dardel F: A generic protocol for the expression and purification of recombinant RNA in Escherichia coli using a tRNA scaffold. Nat Protocols 2009, 4:947-959.

32. Kanaya S: Prokaryotic type 2 RNases H. Methods Enzymol 2001, 341(Pt A):377-394.

33. Inoue $H$, Hayase $Y$, Iwai $S$, Ohtsuka E: Sequence-dependent hydrolysis of RNA using modified oligonucleotide splints and RNase H. FEBS Lett 1987, 215:327-330

34. Lima WF, Mohan V, Crooke ST: The influence of antisense oligonucleotide-induced RNA structure on Escherichia coli RNase H1 activity. J Biol Chem 1997, 272:18191-18199.

35. Pitulle C, Hedenstierna KO, Fox GE: A novel approach for monitoring genetically engineered microorganisms by using artificial, stable RNAs. Appl Environ Microbiol 1995, 61:3661-3666.

36. D'Souza LM, Larios-Sanz M, Setterquist RA, Willson RC, Fox GE: Small RNA sequences are readily stabilized by inclusion in a carrier rRNA. Biotechnol Prog 2003, 19:734-738.

37. Pitulle C, D'Souza L, Fox GE: A low molecular weight artificial RNA of unique size with multiple probe target regions. Syst App/ Microbiol 1997, 20:133-136.

38. Tucker DL, Karouia F, Wang J, Luo Y, Li TB, Willson RC, Fofanov Y, Fox GE: Effect of an artificial RNA marker on gene expression in Escherichia coli. Appl Environ Microbiol 2005, 71:4156-4159.

39. Breaker RR: Natural and engineered nucleic acids as tools to explore biology. Nature 2004, 432:838-845.

40. Breaker RR: Making Catalytic DNAs. Science 2000, 290:2095-2096.

41. Breaker RR, Joyce GF: A DNA enzyme with $\mathrm{Mg}(2+)$-dependent RNA phosphoesterase activity. Chem Biol 1995, 2:655-660.

42. Breaker RR, Joyce GF: A DNA enzyme that cleaves RNA. Chem Biol 1994, 1:223-229.

43. Breaker RR: DNA enzymes. Nat Biotechnol 1997, 15:427-431.

44. Blum H, Beier H, Gross H: Improved silver staining of plant-proteins, RNA and DNA in polyacrylamide gels. Electrophoresis 1987, 8:93-99.

45. Sambrook J, Fritsch EF, Maniatis T: Molecular cloning. Cold Spring Harbor: Cold Spring Harbor Laboratory Pressi" 21989.

46. Girish V, Vijayalakshmi A: Affordable image analysis using NIH Image/ ImageJ. Indian I Cancer 2004, 41:47.

47. Rinehart J, Krett B, Rubio MA, Alfonzo JD, Soll D: Saccharomyces cerevisiae imports the cytosolic pathway for GIn-tRNA synthesis into the mitochondrion. Genes Dev 2005, 19:583-592.

48. Antony T, Thomas T, Shirahata A, Thomas TJ: Selectivity of polyamines on the stability of RNA-DNA hybrids containing phosphodiester and phosphorothioate oligodeoxyribonucleotides. Biochemistry 1999, 38:10775-10784.

49. Thomas T, Thomas TJ: Polyamines in cell growth and cell death: molecular mechanisms and therapeutic applications. Cell Mol Life Sci 2001, 58:244-258.

50. Venkiteswaran S, Vijayanathan V, Shirahata A, Thomas T, Thomas TJ: Antisense recognition of the HER-2 mRNA: effects of phosphorothioate substitution and polyamines on DNA.RNA, RNA.RNA, and DNA.DNA duplex stability. Biochemistry 2005, 44:303-312.

51. Xaplanteri MA, Petropoulos AD, Dinos GP, Kalpaxis DL: Localization of spermine binding sites in $23 \mathrm{~S}$ rRNA by photoaffinity labeling: parsing the spermine contribution to ribosomal 50 S subunit functions. Nucleic Acids Res 2005, 33:2792-2805.

52. Bonaccio M, Credali A, Peracchi A: Kinetic and thermodynamic characterization of the RNA-cleaving 8-17 deoxyribozyme. Nucleic Acids Res 2004, 32:916-925.

53. Cruz RP, Withers JB, Li Y: Dinucleotide junction cleavage versatility of 8-17 deoxyribozyme. Chem Biol 2004, 11:57-67.

54. Liu Z, Mei SH, Brennan JD, Li Y: Assemblage of signaling DNA enzymes with intriguing metal-ion specificities and $\mathrm{pH}$ dependences. J Am Chem Soc 2003, 125:7539-7545.

55. Schlosser K, Gu J, Lam JC, Li Y: In vitro selection of small RNA-cleaving deoxyribozymes that cleave pyrimidine-pyrimidine junctions. Nucleic Acids Res 2008, 36:4768-4777.

56. Zhang X, Potty AS, Jackson GW, Stepanov V, Tang A, Liu Y, Kourentzi K, Strych U, Fox GE, Willson RC: Engineered 5 S ribosomal RNAs displaying aptamers recognizing vascular endothelial growth factor and malachite green. J Mol Recognit 2009, 22:154-161.

57. Chomczynski P, Sacchi N: Single-step method of RNA isolation by acid guanidinium thiocyanate-phenol-chloroform extraction. Anal Biochem 1987, 162:156-159.

58. Chomczynski P, Sacchi N: The single-step method of RNA isolation by acid guanidinium thiocyanate-phenol-chloroform extraction: twentysomething years on. Nat Protocols 2006, 1:581-585.

doi:10.1186/1472-6750-10-85

Cite this article as: Liu et al:: DNAzyme-mediated recovery of small recombinant RNAs from a $5 S$ rRNA-derived chimera expressed in Escherichia coli. BMC Biotechnology 2010 10:85.

\section{Submit your next manuscript to BioMed Central and take full advantage of:}

- Convenient online submission

- Thorough peer review

- No space constraints or color figure charges

- Immediate publication on acceptance

- Inclusion in PubMed, CAS, Scopus and Google Scholar

- Research which is freely available for redistribution

Submit your manuscript at www.biomedcentral.com/submit
C Biomed Central 